\title{
Using Water Balance to Analyze Water Availability for Communities ( A Case Study in Some Areas of Bengawan Solo Watershed)
}

\author{
Alif Noor Anna*, Kuswaji Dwi Priyono, Suharjo, Yuli Priyana \\ Fakultas Geografi, Universitas Muhammadiyah Surakarta \\ Jl. A Yani Tromol Pos 1 Pabelan Surakarta \\ *) Corresponding author (e-mail: alif_noor@ums.ac.id)
}

\begin{abstract}
This study aimed: (a) to determine the general water balance at the Upstream and Midstream of Bengawan Solo Watershed by using Thornthwaite-Mather model, and (b) to determine the fulfillment of domestic water demand in the Upstream and Midstream of Bengawan Solo Watershed. Prevailing climate change has affected the condition of water source in Upstream and Midstream of Bengawan Solo Watershed. One of the impacts was extreme fluctuation of meteorological water availability that might cause flood and drought. Survey was selected as the research method while descriptive quantitative method was used for data analysis. The findings indicated the difference between precipitation and corrected evapotranspiration $(P-E P)$ at the Upstream and Midstream of Bengawan Solo Watershed was between (-11.19 $\mathrm{mm})$ to $(78.56 \mathrm{~mm})$. The highest value was obtained by Bambang Sub-watershed and the lowest was Wiroko Temon Sub-watershed. Positive value indicated the water surplus while negative value indicated water deficit. Domestic water demand for local communities was in the range of 50,782,500 liters to 131,690,700 liters, and the level of water availability varied, namely fulfilled and unfulfilled.
\end{abstract}

Keywords: General water balance, water availability, water demand, Bengawan Solo Watershed, Indonesia.

\begin{abstract}
Abstrak. Penelitian ini bertujuan: (a) untuk menentukan neraca air umum di Hulu dan tengah sungai Bengawan Solo DAS dengan menggunakan model Thornthwaite-Mather, dan (b) untuk menentukan pemenuhan kebutuhan air domestik di Hulu dan tengah sungai Bengawan Solo DAS . Berlaku perubahan iklim telah mempengaruhi kondisi sumber air di Hulu dan tengah sungai Bengawan Solo DAS. Salah satu dampak adalah fluktuasi ekstrim ketersediaan air meteorologi yang mungkin menyebabkan banjir dan kekeringan. Survei terpilih sebagai metode penelitian sedangkan metode deskriptif kuantitatif digunakan untuk analisis data. Temuan menunjukkan perbedaan antara curah hujan dan dikoreksi evapotranspirasi $(P-E P)$ di Hulu dan tengah sungai Bengawan Solo DAS adalah antara $(-11,19 \mathrm{~mm}) \mathrm{ke}(78,56 \mathrm{~mm})$. Nilai tertinggi diperoleh oleh Bambang Sub-DAS dan terendah adalah Wiroko Temon Sub-DAS. Nilai positif menunjukkan surplus air sementara nilai negatif menunjukkan defisit air. kebutuhan air domestik bagi masyarakat lokal di kisaran 50.782.500 liter untuk 131.690.700 liter, dan tingkat ketersediaan air bervariasi, yaitu terpenuhi dan tidak terpenuhi.
\end{abstract}

Kata kunci: neraca air umum, ketersediaan air, kebutuhan air, Bengawan Solo Daerah Aliran Sungai, Indonesia.

\section{Introduction}

Climate change had been one of national strategic issues that challenged the Indonesian government in the efforts to minimize its negative impacts. Despite the assumption that global warming is a natural cycle and has been taking place since the early days of the Earth, the process is escalated that causes climate change and other adverse impacts on the Earth and life within (Sakuntaladewi and Wibowo, 2015). Numbers of evidences have been systematically reported by official agencies, including Intergovernmental Panel on Climate Change (IPCC) and The United 
Nations Framework Convention on Climate Change (UNFCCC). Their reports highlighted the immediate hazard of climate change such as the changes of precipitation pattern, rising temperatures, sea level rise, and extreme climate events. Those potential hazards threaten and affect the sustainability of community and natural system (National Defence Institute/ Lemhanas, 2014). One of natural systems highly influenced by the climate change was watershed. However, climate changes had both positive and negative impacts on watershed. Generally, the Upstream and Midstream of Bengawan Solo Watershed endured adverse impact of climate change, including drought and flood.

In a study, Foster and Ait-Kadi (2012) reaffirmed that climate change will convey negative consequence on the sector of water resources and economic stability. The availability of water resources became a global warning that should be resolved immediately. Moreover, human interferences such as area development, population pressure, and rapid urbanization had worsened the situation. Similarly, Adi (2015) confirmed that global climate change has provided evidences in Indonesia, particularly related with precipitation pattern. Extreme rainfall frequency and intensity increased the occurrence of flash flood and landslide. In addition, the elongated duration of the dry season had caused drought, forest fires, and degraded land. Luo, et al (2013) also suggested that the impacts of climate change could lead to volatility of hydrological cycle and water quality in a watershed.

Watershed is one of the determinants of water resources status in a given area. However, the condition of watersheds in Indonesia are commonly degraded over time (Miardini and Susanti, 2016). Improper watershed management will have an adverse impact on its water resources status. There was a wide range of strategic issues regarding with water resources sector that should be addressed as an effort in response to global climate change at the Upstream and Midstream of Bengawan Solo Watershed. The strategic issues consisted of: (a) the water balance between the supply and the demand (water balance). Climate change potentially threatened the decline of water supply, floods, and droughts, thus, the vulnerability and risks should be recognized specifically in order to identify important adaptation measures, (b) the inadequate condition of water infrastructure that led to an increase of climate change risk on the water sector, and (c) the lack of technology implementation and inappropriate water resources management.

Rapid population growth resulted in higher demand for water resources. However, higher individual socio-economic status would be followed by higher consumption level including on water resources such as for trade and industrial activity. The necessity for water resources sector in urban areas was greater in quantity in compared with rural areas. It was confirmed by (Varris, et al., 2006) who emphasized that rapid population growth in major cities had increased the demand for water resources, and uncontrolled exploitation would affect the water supply. To maintain water supply, water resources management and planning was required including by the determination of regional water balance.

This study aimed to determine the general water balance at the Upstream and Midstream of Bengawan Solo Watershed by using Thornthwaite-Mather model, and to determine the level of domestic water fulfillment in the study area.

\section{Research Methods}

\section{a. Methods}

Secondary analysis data was the method employed in this study and descriptive quantitative method was used for data analysis. Furthermore, the determination of watershed's general water balance used ThornthwaiteMather method. Watershed's meteorological water availability was assessed by using the weighted average method.

\section{b. Data and Data Sources}

In this study, the data comprised of secondary data that was supported with field study results. Specifically, the data and sources are presented in Table 1 as follows. 
Table 1. Data and Data Sources

\begin{tabular}{|c|c|c|c|c|}
\hline No & Analysis & Data & Specific Data & Source \\
\hline \multirow[b]{2}{*}{1} & & $\begin{array}{l}\text { Meteorological } \\
\text { data }\end{array}$ & $\begin{array}{l}\text { Average monthly } \\
\text { precipitation and tem- } \\
\text { perature }\end{array}$ & $\begin{array}{l}\text { BPTKP DAS Benga- } \\
\text { wan Solo, Balai PSDA } \\
\text { Bengawan Solo }\end{array}$ \\
\hline & General water balance & Maps & $\begin{array}{l}\text { Soil map, Geology, } \\
\text { Slope, Land use, and } \\
\text { Watershed }\end{array}$ & Previous studies \\
\hline 2 & Water demand & Population Data & $\begin{array}{l}\text { Data of total popula- } \\
\text { tion and population } \\
\text { growth }\end{array}$ & Badan Pusat Statistik \\
\hline
\end{tabular}

Source: Authors, 2015.

\section{Data Analysis Technique}

\section{a. General water balance analysis}

Water balance is the balance of the water input and output in a region at a certain period that can be used to determine the amount of water surplus or water deficit. The model used in this study was the general water balance. It required climatological data and was useful to determine the wet months. ThornthwaiteMather method was used to identify the condition of the water quantity in each month in a year (Fu'adah, et al., 2015). This method measured air temperature, monthly heat index, and correction factor of solar radiation duration based on the latitude (Tamba, et al., 2016). Projection of domestic water demand was established by considering the rate of population growth.

\section{b. Water availability analysis}

The weighted average method was employed to calculate water availability based on precipitation of each sub-watershed (Muliranti and Hadi, 2013). The equation was as follows:

$\mathrm{V}=(\mathrm{P} 1 \mathrm{xA} 1)+(\mathrm{P} 2 \mathrm{xA} 2)+(\mathrm{P} 3 \mathrm{xA} 3)$

Where:

$\mathrm{V} \quad$ : volume (water availability in liters $\left./ \mathrm{m}^{3}\right)$,

P1. P2. P3 : precipitation ( $\mathrm{mm})$, and

A1. A2. A3 : area of the Upstream and Midstream of Bengawan Solo Watershed $\left(\mathrm{km}^{2}\right)$.

\section{c. Domestic Water Demand Fulfillment Analysis}

The fulfillment of domestic water demand in the study area was assessed based on the ratio of regional meteorological water availability and domestic water demand in Bengawan Solo Watershed. Demand was fulfilled if water availability exceeded the demand and on the contrary, it was not fulfilled if water availability was lower than the demand.

The calculation of domestic regional water availability was carried out by using the weighted average method and domestic water demand by the assumption of 100 liters / individual/ day (Muliranti and Hadi, 2013).

\section{Results and Discussions}

\section{a. Physical Condition of Study Area}

The Upstream and Midstream of Bengawan Solo watershed consist of several sub-watersheds including Pepe, Bambang, Dengkeng, Mungkung, Samin, and Jlantah Walikun Ds, Keduang, Wiroko Temon, and Alang Unggahan. Astronomically, the study area is situated at $110^{\circ} 13^{\prime} 7,16^{\prime \prime} \mathrm{E}-110^{\circ} 26^{\prime} 57,10^{\prime \prime} \mathrm{E}$ and $7^{\circ} 26^{\prime} 33,15^{\prime \prime} S-8^{\circ} 6^{\prime} 13,81^{\prime \prime}$ S. Total area was $3773.99 \mathrm{~km}^{2}$. Administratively, the Upstream of Bengawan Solo Watershed covered Wonogiri district, Sukoharjo district, Klaten district, Karanganyar district, Boyolali district, and Surakarta City. Spatially, the illustration of study area can be observed in Fig. 1 .

The micro climate of each sub-watershed was determined by using Thiessen polygons. It was established with five rainfall stations, thus, there were five Thiessen polygon areas, namely Nepen station (Boyolali), Pabelan station (Surakarta), Klaten station, Tawangmangu station (Karanganyar), and Baturetno station 
(Wonogiri). Based on the analysis obtained from those stations, the study area had moderate and semi-humid climate. Rainfall stations classified in semi-humid climate group were Pabelan, Tawangmangu, and Klaten with the $\mathrm{Q}$ values, respectively, 43.2: 39.5: and 50. Meanwhile, rainfall stations located in moderate climate were Nepen and Baturetno with $Q$ values of 62.8 and 96.6, respectively. Spatial Thiessen polygon of the study area is presented in Fig. 2.

In 2014, there were 7 (seven) types of land use were recorded in the study area, namely, forest, mixed orchard, vacant land, settlement, paddy field, dry-land agriculture, and reservoir. Land use was dominated by paddy field and mixed orchard with area of $1146.51 \mathrm{~km}^{2} 1190.76$ $\mathrm{km}^{2}$, respectively.

Generally, the soil type of the study area consisted of eight types, including alluvials, andosols, complex, grumusols, latosols, lithosols, mediterranean, and regosols. Lithosol dominated the study area and was distributed evenly throughout the area, approximately of $1465.3 \mathrm{~km}^{2}$. This kind of soil has a thickness or soil solum of $20 \mathrm{~cm}$ or less on the surface of source rock or source material (lytic or paralytic) regardless the color and texture.

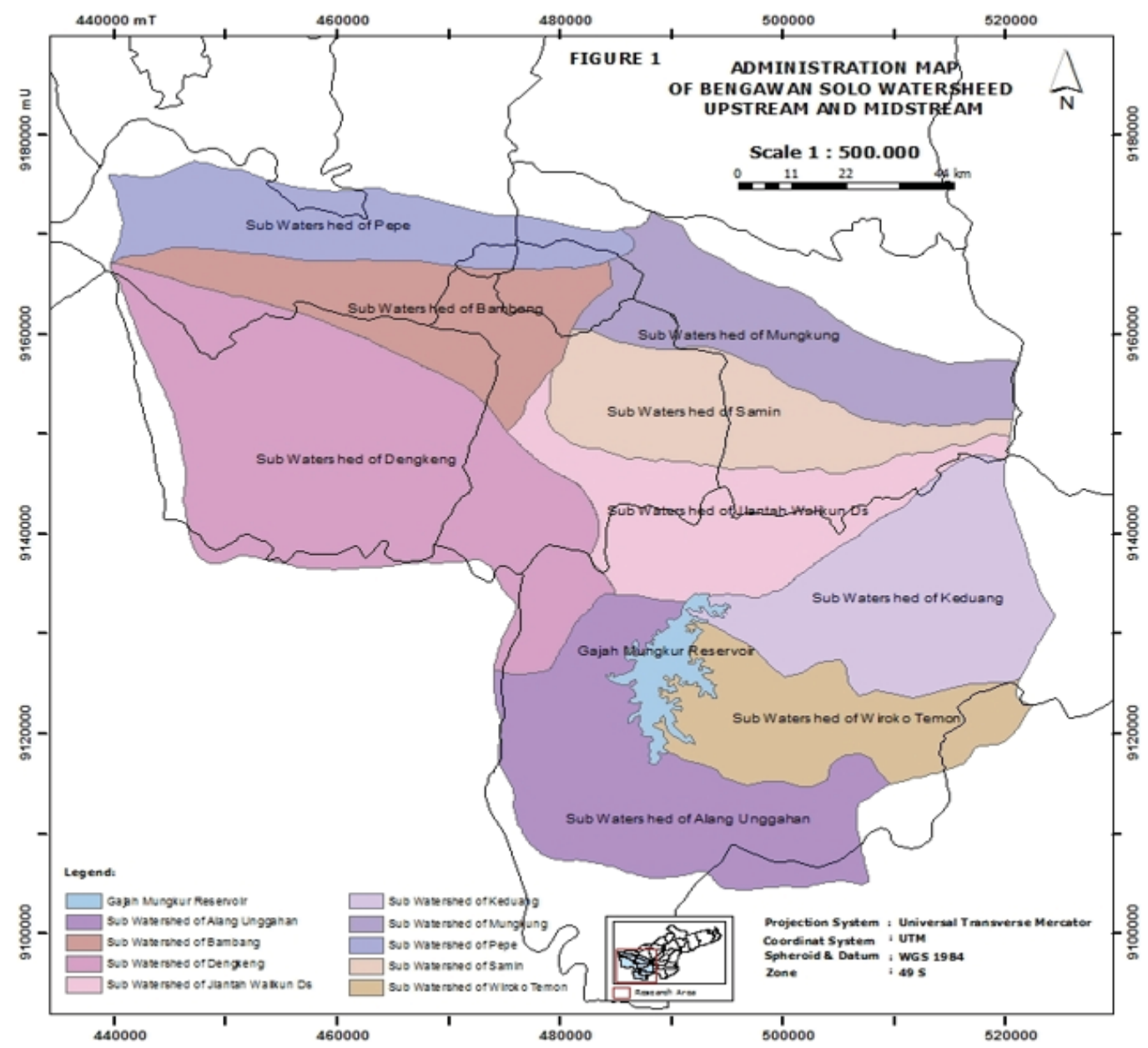

Figure 1. Administration Map of the Upstream and Midstream of Bengawan Solo Watershed.

The study area was divided into four topography regions, i.e. flat, undulating, hilly, and volcanic. This study area was generally flat (slope of $0-<5 \%$ ) with a total area of $2506.10 \mathrm{~km}^{2}$ or $66.4 \%$ of the total regional area. It indicated that the dominant topography was relatively flat. Other parts were dominated by a slope of $10-<30 \%$ of approximately $931.15 \mathrm{~km}^{2}$. It was distributed on the edge of the study area, including on the south, east, and west of the area. In addition, there was a small part of area with a slope of $5-<10 \%$ and $>30 \%$ (Suharjo and Anna, 2007). 


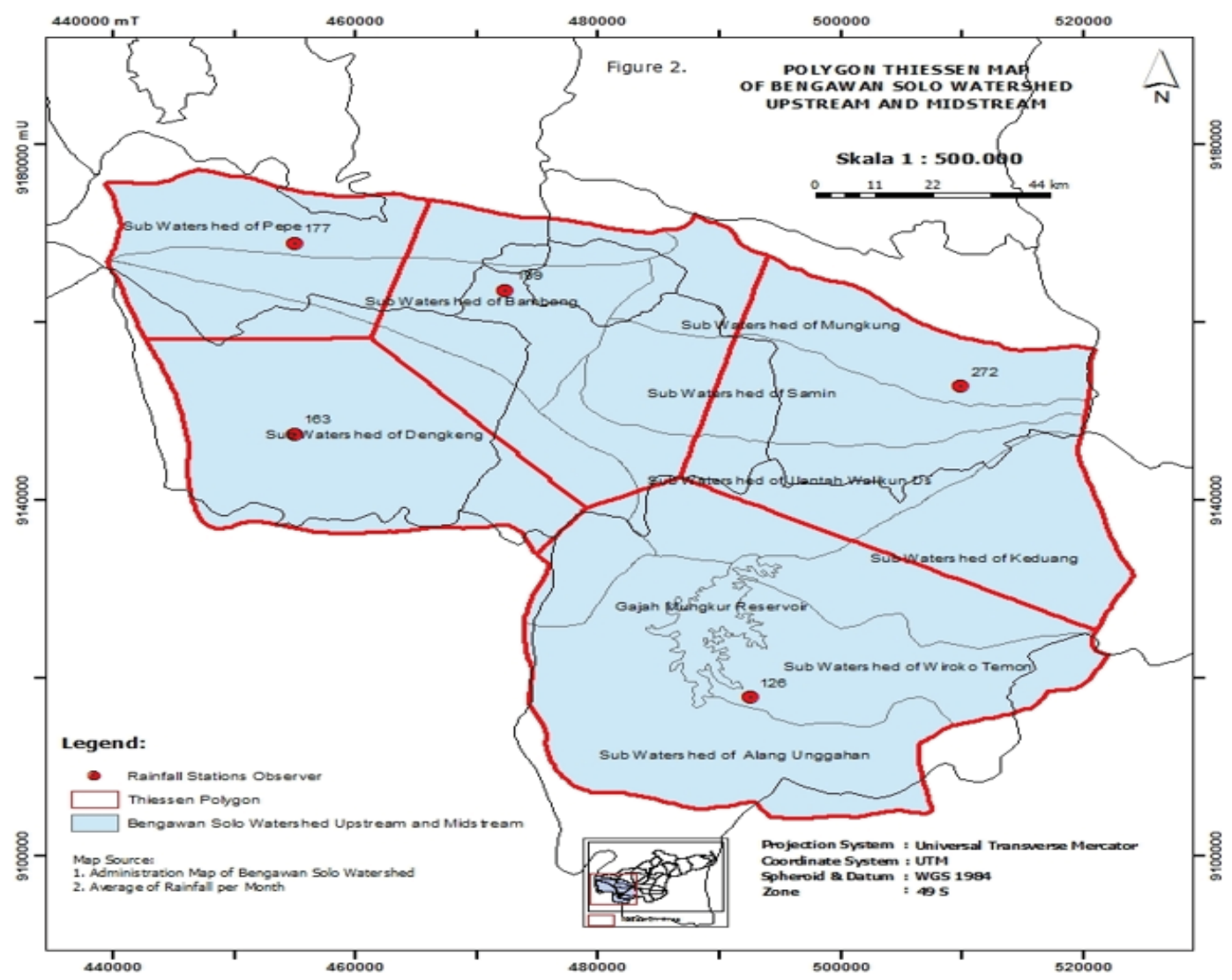

Figure 2. Polygon Thiessen Map of the Upstream and Midstream of Bengawan Solo Watershed.

Geologically, the Upstream and Midstream of Bengawan Solo Watershed were constituted of Andesite, Holocene, Alluvium, Limestone, Old Quaternary Volcanic Product, Quaternary Sedimentary Product, Tertiary Sedimentary Product, Tertiary Volcanic Product, and Young Quaternary Volcanic Product. The Upstream and Midstream of Bengawan Solo Watershed were dominated by Young Quaternary Volcanic Product that was evenly distributed in the west and the east with total area of $2002.5 \mathrm{~km}^{2}$. This area was constituted of materials from Mount Merapi and Lawu since the study area is located between Mount Merapi and Lawu in the west and the east. Meanwhile, Bengawan Solo River is situated between Mount Merapi and Lawu, so there were holocene and alluvium that were composed from the river sediment material with an area of $435.4 \mathrm{~km}^{2}$.

Based on data from the Central Bureau of Statistics (Badan Pusat Statistik) in 2015, the total population of the six districts included in the Upstream and Midstream of Bengawan Solo Watershed was 5,420,625 people, with an average population growth of $0.82 \%$ per year. The population data of the study area can be seen in Table 2.

Table 2. Population in the Study Area in 2014.

\begin{tabular}{llcc}
\hline No & \multicolumn{1}{c}{ District/City } & $\begin{array}{c}\text { Total Population } \\
\text { (individual) }\end{array}$ & Population Growth (\%) \\
\hline 1 & Sukoharjo & 849,506 & 0.45 \\
2 & Karanganyar & 840,171 & 0.71 \\
3 & Surakarta City & 507,825 & 1.53 \\
4 & Boyolali & 963,839 & 0.64 \\
5 & Klaten & $1,316,907$ & 1.02 \\
6 & Wonogiri & 942,377 & 0.56 \\
\hline
\end{tabular}

Source: Data analysis, 2015. 
b. General Water Balance in the Upstream and Midstream of Bengawan Solo Watershed

Based on the water cycle system, the water available on the earth is the result of precipitation. Rainwater poured down on the earth's surface in various conditions of land cover including in urban area, rural area, forest, fields, diverse soil types and topographies. Different land conditions would differentiate the quantity of water related to the process of infiltration, evaporation, storage by the crowns and hollows, as well as runoff. The conditions indicated that the physical and meteorological components had effect on water availability (hydrological conditions) in a watershed.

The final result of watershed's general water balance was derived from the difference between precipitation and corrected $\mathrm{EP}$, thus, water surplus or water deficit in the wet period could be determined. Negative value represented the precipitation level was incapable to add water potential of vegetated area. On the contrary, positive value depicted the water surplus was available during certain periods of the year to restore soil moisture and runoff. The differences between precipitation and monthly P-EP in the Upstream and Midstream of Bengawan Solo Watershed are presented in Table 3.

Table 3. The Calculation of Monthly P-EP in the Upstream and Midstream of Bengawan Solo Watershed.

\begin{tabular}{clcccc}
\hline No & Sub-watershed & P & EP & P-EP & Description \\
\hline 1 & Alang Unggahan & 126 & 135.67 & -9.67 & Deficit \\
2 & Bambang & 192.06 & 113.50 & 78.56 & Surplus \\
3 & Dengkeng & 165.94 & 125.70 & 40.24 & Surplus \\
4 & Jlantah Walikun Ds & 218.44 & 123.20 & 95.24 & Surplus \\
5 & Keduang & 217.38 & 122.40 & 94.98 & Surplus \\
6 & Mungkung & 248.51 & 169.70 & 78.81 & Surplus \\
7 & Pepe & 184.84 & 117.66 & 67.18 & Surplus \\
8 & Samin & 244.82 & 174.00 & 70.82 & Surplus \\
9 & Wiroko Temon & 126 & 137.19 & -11.19 & Deficit \\
\hline
\end{tabular}

Source: Data analysis, 2014

In Table 3, the Upstream and Midstream of Bengawan Solo Watershed endured water deficit and water surplus. The highest value of P-EP was obtained by Keduang sub-watershed and the lowest was obtained by Wiroko Temon sub-watershed. Water deficit was undergone by Alang Unggahan and Wiroko Temon sub- watershed. It was allegedly caused by those sub-watersheds were in the range of one rainfall station, which was Baturetno station. The condition of meteorological water deficit and water surplus in the Upstream and Midstream of Bengawan Solo Watershed is presented in Fig. 2.

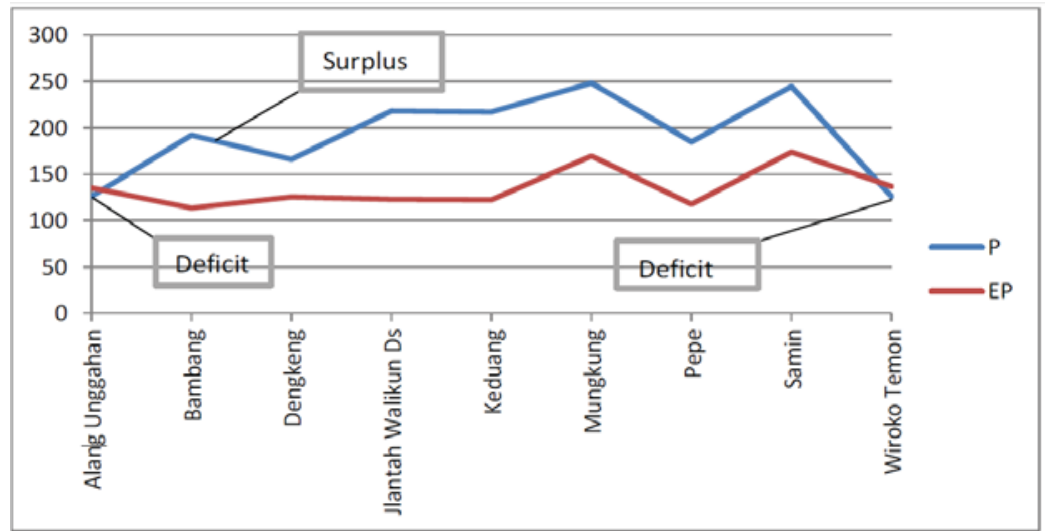

Figure 3. General Water Balance of the Upstream and Downstream of Bengawan Solo Watershed. 
Based on Fig. 3, the blue line showed the data of average monthly precipitation and the red line indicated the corrected potential evaporation. Water deficit occurred when the two curves intersected.

The assessment of general water balance in the Upstream and Midstream of Bengawan Solo watershed required the data of average monthly precipitation rainfall by employing Thornthwaite-Mather method. This method was selected since numbers of researchers verified the high accuracy of this method. Calvo (2009) conducted a study of the evaluation of water balance by using Thronwaite-Matter in predicting run-off in the highlands of Costa Rica. The results indicated that the ThronwaiteMatter method could estimate annual and monthly run-off and in general, the level of results' accuracy reached $90 \%$.

Similar study related with the calculation of P-EP by employing the Thronwaite-Matter method was also carried out by Adi (2015) to describe the drought of an area with Index of Aridity (Ia). It compared the difference between water deficit and potential evaporation. Based on the results of the study conducted in the Code watershed based on Ia, the area could be classified as $r$ (low water deficit). Thus, climatologically, the area of Code watershed could not be considered as drought-vulnerable area.

\section{c. Domestic Meteorological Water Availability}

Meteorological water availability in the Upstream and Midstream of Bengawan Solo Watershed was obtained from the average of monthly precipitation derived from Thiessen polygons method. Data processing was carried out with the assistance of Geographic Information Systems (GIS) by using Arc GIS 9.3 software. Specifically, results of data processing are presented in Table 4.

Table 4. Monthly Meteorological Water Availability in the Upstream and Midstream of Bengawan Solo Watershed.

\begin{tabular}{clccc}
\hline No & Sub-watershed & Precipitation $(\mathbf{m m})$ & Total Area $\left.\mathbf{( k m}^{2}\right)$ & $\begin{array}{c}\text { Water Availability } \\
(\mathbf{l i t e r})\end{array}$ \\
\hline 1 & Alang Unggahan & 126 & 508.82 & $64,111.32$ \\
2 & Bambang & 192.06 & 321.23 & $61,695.43$ \\
3 & Dengkeng & 165.94 & 861.11 & $142,892.59$ \\
4 & Jlantah Walikun Ds & 218.44 & 365.58 & $79,857.30$ \\
5 & Keduang & 217.38 & 423.25 & $92,006.09$ \\
6 & Mungkung & 248.51 & 324.93 & $80,748.35$ \\
7 & Pepe & 184.84 & 296.53 & $54,810.61$ \\
8 & Samin & 244.82 & 314.64 & $77,030.16$ \\
9 & Wiroko Temon & 126 & 297.3 & $37,459.80$ \\
& $\quad$ Total & 1723.99 & 3713.39 & $690,611,650$ \\
\hline
\end{tabular}

Source: Data analysis, 2014.

Based on Table 4, the highest value of meteorological water availability was obtained by Dengkeng sub-watershed of 142,892.59 liters while the lowest was obtained by Wiroko Temon sub-watershed of 37,459.8 liters. The difference was the consequence of total area, meteorological stations range, and the mean precipitation of each sub-watershed. Administratively, Sukoharjo covered Samin sub-watershed, Karanganyar covered Mungkung sub-watershed, Boyolali covered Bambang sub-watershed, Surakarta covered Pepe sub-watershed, Klaten covered Dengkeng sub-watershed, and Wonogiri covered Jlantah Walikun Ds, Alang Unggahan, Keduang, and Wiroko Temon sub-watershed.

Thiessen polygon method to determine the average precipitation has several advantages including to provide precise precipitation data since each part of the catchment area is proportionally represented by specific rain gauge that could be used on large area. It was confirmed by research conducted by Ning (2012) that used Thiessen polygon method to calculate and estimate the rainfall distribution of other areas with the absence of precipitation data in a given period. 
Data of meteorological water availability that had been calculated by using Thiessen polygon method and divided into sub-watershed area, subsequently, was changed into administrative- based data. As for the details of meteorological water availability based on administrative area of the Upstream and Midstream of Bengawan Solo watershed is presented in Table 5.

Table 5. Monthly Meteorological Water Availability in the Upstream and Midstream of Bengawan Solo Watershed.

\begin{tabular}{|c|c|c|c|}
\hline No & District/City & Range of Sub-watershed & $\begin{array}{c}\text { Water Availability } \\
\text { (liter) }\end{array}$ \\
\hline 1 & Sukoharjo & Samin & $77,030,160$ \\
\hline 2 & Karanganyar & Mungkung & $80,748,350$ \\
\hline 3 & Surakarta & Pepe & $54,810,610$ \\
\hline 4 & Boyolali & Bambang & $61,695,430$ \\
\hline 5 & Klaten & Dengkeng & $142,892,590$ \\
\hline 6 & Wonogiri & $\begin{array}{l}\text { Jlantah Walikun Ds, Alang Un- } \\
\text { ggahan, Keduang, and Wiroko } \\
\text { Temon }\end{array}$ & $273,434,510$ \\
\hline \multicolumn{3}{|c|}{ Total } & $690,611,650$ \\
\hline
\end{tabular}

Source: Data analysis, 2015

In accordance to Table 5, the highest monthly meteorological water availability was attained by Wonogiri district, which was amounted to $273,434,51$ liters and the lowest was obtained by Surakarta City of 54,810,61 liters. High meteorological water availability should be necessarily balanced with well-managed water conservation such as by expanding the catchment area, reducing land-use conversion, harvesting rainwater, and reducing excessive use of ground water. It was also emphasized by Basuki (2015) that water conservation techniques of inundation/reservoir system can be an alternative to decrease the run off.

\section{d. Analysis of Domestic Water Demand in the Upstream and Midstream of Bengawan Solo Watershed}

Water is one of the basic necessities for local community in the Upstream and Midstream of Bengawan Solo watershed. It is used for various purposes including for domestic and agricultural activities. Water demand of each area varies in accordance to the population and their livelihoods. In this study, water demand was estimated based on the assumption in which each individual required 100 liters/ day. The domestic water demand of districts in the administrative area of Upstream and Midstream of Bengawan Solo watershed is presented in Table 6.

Based on Table 6, the highest level of domestic water demand was obtained by Klaten district of $131,690,700$ liter, while the lowest domestic water demand was attained by Surakarta City of 50,782,500 liters. The level of domestic water demand in the study area varied that was caused by diverse total population of each district or city in the administrative area of the Upstream and Midstream of Bengawan Solo watershed. The higher the population of an area, the higher the domestic water demand. However, clean water demand was not linear with the supply, hence, people should frequently buy clean water at areas with abundant clean water. Similarly, Alimah and Putro (2015) asserted water demand as human basic requirement is inclined to augment in accordance to population growth. The demand is increasing for household, industry sector, offices, and other public facilities.

Table 6. Domestic Water Demand in 2015 at the Administrative Area of the Upstream and Midstream of Bengawan Solo Watershed.

\begin{tabular}{rlrrr}
\hline No & District/City & $\begin{array}{c}\text { Total Population } \\
\text { (individual) }\end{array}$ & $\begin{array}{c}\text { Standard } \\
\text { requirement (liter) }\end{array}$ & Demand (liter) \\
\hline 1 & Sukoharjo & 849,506 & 100 & $84,950,600$ \\
2 & Karanganyar & 840.171 & 100 & $84,017,100$ \\
\hline
\end{tabular}




\begin{tabular}{rlrrrr}
\hline No & District/City & $\begin{array}{c}\text { Total Population } \\
\text { (individual) }\end{array}$ & $\begin{array}{c}\text { Standard require- } \\
\text { ment (liter) }\end{array}$ & Demand (liter) \\
\hline 3 & Surakarta & 507,825 & 100 & $50,782,500$ \\
4 & Boyolali & 963,839 & 100 & $96,383,900$ \\
5 & Klaten & $1,316,907$ & 100 & $131,690,700$ \\
6 & Wonogiri & 942,377 & 100 & $94,237,700$ \\
& & $5,420,625$ & 600 & $542,062,500$ \\
\hline
\end{tabular}

Source: Data analysis, 2015.

e. Analysis of Domestic Water Demand Fulfillment in the Study Area

The fulfillment of domestic water demand was based on the amount of meteorological water availability and the amount of domestic water demand of the population in a certain region. High meteorology-based water availability and low water demand would result on the fulfillment of domestic water demand, on the contrary, low meteorology-based water availability and high water demand would lead to water deficit. The fulfillment of domestic water demand in the Upstream and Midstream of Bengawan Solo Watershed is presented in Table 7.

Table 7. The Status of Domestic Water Demand in Upstream and Midstream of Bengawan Solo Watershed.

\begin{tabular}{lrrrl}
\hline \multicolumn{1}{c}{ District/City } & \multicolumn{1}{c}{$\begin{array}{c}\text { Availability } \\
\text { (liter) }\end{array}$} & Demand (liter) & Difference & Description \\
\hline Sukoharjo & $77,030,160$ & $84,950,600$ & $-7,920,440$ & Deficit \\
Karanganyar & $80,748,350$ & $84,017,100$ & $-3,268,750$ & Deficit \\
Surakarta & $54,810,610$ & $50,782,500$ & 4.028 .110 & Surplus \\
Boyolali & $61,695,430$ & $96,383,900$ & $-34,688,470$ & Deficit \\
Klaten & $142,892,590$ & $131,690,700$ & $11,201,890$ Surplus \\
Wonogiri & $273,434,510$ & $94,237,700$ & $179,196,810$ & Surplus \\
& $690,611,650$ & $542,062,500$ & $148,549,150$ & Surplus \\
\hline
\end{tabular}

Source: Data analysis, 2015.

Table 7 demonstrated that basically, domestic water demand in the study area was fulfilled. However, several districts had endured water deficit as can be seen in Table 7, such as Sukoharjo district, Karanganyar district, and Boyolali district. The status eventually improved community welfare and life quality. Surplus or deficit domestic water availability of study area in this research, however, did not reflect the water crisis since most of the population lived in the urban area and utilized local water company (PDAM) as water source.

\section{Conclusion}

Based on the results description and discussion, it can be concluded that the calculation of general water balance in the
Upstream and Midstream of Bengawan Solo watershed indicated the occurrence of both water surplus and water deficit. Water surplus was obtained by Bambang, Dengkeng, Jlantah Walikun Ds, Keduang, Mungkung, Pepe and Samin sub-watershed, while water deficit was undergone by Alang Unggahan and Wiroko Temon sub-watershed. The meteorological water availability in the Upstream and Midstream of Bengawan Solo watershed was in the range of $37,459,800$ to $142,892,590$ liters. Domestic water demand in Upstream and Midstream of Bengawan Solo watershed was between $50,782,500$ to $131,690,700$ liters. The water availability generally fulfilled the water demand, thus, the community requirement for domestic water demand was attained.

\section{References}

Adi, R.N., 2015. Klasifikasi Iklim dan Intensitas Kekeringan Daerah Aliran Sungai Code berdasarkan Indeks Kekeringan. Makalah Seminar Nasional Restorasi DAS. Surakarta: BPTKPDAS. 
Alimah, I., Putro, H P H., 2015. Kajian Tingkat Konsumsi Air Bersih PDAM di Provinsi Jawa Barat. Jurnal Perencanaan Wilayah dan Kota B SAPPK V3 N2 p:305-314.

Basuki, T.M., 2015. Evaluasi Kemampuan Penggunaan Lahan dan Alternatif Penerapan Konservasi Tanah dan Air Sebagai Upaya Restorasi DAS Ciliwung. Makalah Seminar Nasional Restorasi DAS. Surakarta: BPTKPDAS.

Calvo, J.C., 2009. An evaluation of Thornthwaite's water balance technique in predicting stream runoffin Costa Rica. Hydrological Sciences Journal,31:1,51-60, DOI:10.1080/02626668609491027.

Fu'adah, A.T., Iryanti, M., Mujtahiddin, M I., 2015. Analisis Spasial Ketersediaan Air Tanah di Wilayah Bandung dengan menggunakan Metode Neraca Air Thornthwaite-Matter. Jurnal Penelitian Fibusi (JoF), Vol. 3 No. 1 April 2015. Bandung: Jurusan Pendidikan Fisika, Fakultas Pendidikan Matematika dan Ilmu Pengetahuan Alam Universitas Pendidikan Indonesia (UPI).

Lemhanas, 2014. Problem Sumber Daya Air dan Model Pengelolannya. Accessed in 28 April 2014 at:

http://www.lemhannas.go.id/portal/images/stories/humas/jurnal/edisi15/jurnal\% 20 edisi\%2015materi\%206.pdf.

Miardini, A., Susanti, P.D., 2016. Analysis Physical Characteristics of Land for Estimated Runoff Coefficient as Flood Control Effort in Comal Watershed, Central Java. Forum Geografi 30, 58-68.

Muliranti , S., Hadi, M. Pramono., 2013. Kajian Ketersediaan Air Meteorologis untuk Pemenuhan Kebutuhan Air Domestik di Provinsi Jawa Tengah dan DIY. Naskah Publikasi Skripsi S1. Yogyakarta: Fakultas Geografi UGM

Ningsih, D. H.U., 2012. Metode Thiessen Polygon untuk Ramalan Sebaran Curah Hujan Periode Tertentu pada Wilayah yang Tidak Memiliki Data Curah Hujan. Jurnal Teknik Teknologi Informasi DINAMIK. 17(2):156.

Suharjo, Anna, A. N., 2007. Evolusi Lereng Dan Tanah Daerah Solo Jawa Tengah. Fakultas Geografi UMS.

Foster, S. and Ait-Kadi, M. 2012. Integrated Water Resources Management (IWRM): How does groundwater fit in?. Hydrogeology Journal. 20: 415-418. Sweeden: Springer-Verlag.

Sakuntaladewi, N., Wibowo, L. R., 2015. Dampak Perubahan Iklim, Kerentanan, dan Adaptasi Masyarakat di DAS Cipunagara, Provinsi Jawa Barat. Makalah Seminar Nasional Restorasi DAS. Surakarta: BPTKPDAS.

Tamba, C., Fauzi, M., Suprayogi, I., 2016. Kajian Potensi Ketersedian Air menggunakan Model Neraca Air Bulanan Thornthwaite-Mather (Studi Kasus: Sub Das Subayang Kampar Kiri Hulu). Jurnal Penelitian Jom FTEKNIK Volume 3 NO. 2 Oktober 2016 pp: 1-8. Riau: Jurusan Teknik Sipil Fakultas Teknik Universitas Riau. 